\title{
PENGEMBANGAN PROGRAM NOTIFIKASI BERBASIS KOMPUTER UNTUK MEMPERLANCAR PROSES PENGEMBALIAN BUKU PINJAMAN PADA PERPUSTAKAAN UNIVERSITAS PENDIDIKAN GANESHA
}

\author{
Ni Putu Pramita Utami ${ }^{1}$, I Made Putra Subagia Antara ${ }^{2}$ \\ 1,2 Unit Perpustakaan, Universitas Pendidikan Ganesha, Singaraja, Indonesia \\ e-mail: pramitautami@yahoo.com; mdpantara@gmail.com
}

\begin{abstract}
Abstrak
Penelitian ini bertujuan untuk (1) mengembangkan program notifikasi berbasis komputer dengan program facebook untuk memperlancar proses pengembalian buku pinjaman pada perpustakaan Undiksha, (2) mengetahui kualitas program notifikasi berbasis komputer via facebook berdasarkan hasil validasi, dan (3) mengetahui efektifitas program notifikasi berbasis komputer dengan program facebook dalam memperlancar proses pengembalian buku pinjaman pada perpustakaan Undiksha. Program notifikasi tersebut masih bersifat sederhana dan semi otomatis yang melibatkan langkah-langkah (1) pendeteksian pemustaka yang meminjam bahan pustaka 3 hari sebelum batas akhir peminjaman dalam dbase perpustakaan Undiksha, (2) data itu kemudian diunggah ke website Undiksha, (3) dari website Undiksha kemudian dishare dengan facebook melalui fasilitas share, dan (4) nama akun pemustaka tersebut kesemuanya di add dan dikirimi notifikasi. Hasil validasi yang dilakukan menunjukkan bahwa dari segi keandalan (reliability), kebenaran (correctness), kemampuan menggunakan (useability), kemampuan memelihara (maintainability), kemampuan uji (testability), kemampuan interoperasi (interoperationalibility), keluwesan (flexibility), dan kepuasan menyeluruh (overall satisfaction) program sudah cukup baik. Program notifikasi tersebut juga sudah cukup memuaskan dari segi isi dan tampilan muka. Hasil ujicoba juga menunjukkan bahwa program tersebut mampu untuk meminimalisir prosentase keterlambatan pengembalian bahan pustaka.
\end{abstract}

Kata kunci: program notifikasi, facebook dan bahan pustaka 


\begin{abstract}
The aims of the reserach were to (1) develop notification program via facebook in the attempt to smoothen the process of loan books' returns, (2) know the quality of the notification program via facebook based on the result of validation, and (3) know the effectivity of the notification program via facebook in the attempt to smoothen the process of loan books' return. The program developed were still simple and semi automatic involving the following steps of (1) detecting those users that borrow library's books, (2) uploading those data to Undiksha website, (3) sharing with the facebook from the website through share facility and (4) adding the user accounts and sending the notification. The results of the validation showed that in terms of reliability, correctness, useability, maintainability, testability, interoperationalibility, flexibility and overall satisfaction the program had shown good performance. The content and layout of the notification itself were also quite good. Besides, the results of try out also showed that the program can minimize the percentage the lateness of the books loan.
\end{abstract}

Keywords: notification program, facebook and book collection

\section{PENDAHULUAN}

Pesatnya perkembangan teknologi informasi termasuk di dalamnya komputer dan telekomunikasi, menyebabkan hampir sebagian besar kegiatan di berbagai bidang telah memanfaatkan komputer. Hal ini bisa di lihat dari maraknya penggunaan telepon genggam yang dilengkapi dengan berbagai fitur GSM seperti layanan internet termasuk maraknya pengaplikasian situs facebook. Sebagaimana diketahui, facebook merupakan jejaring sosial yang difungsikan untuk menyebarkan berbagai informasi secara cepat, tepat dan aktual dalam suatu ikatan individu maupun kelompok tanpa batasan ruang dan waktu. Tentunya fenomena seperti itu sedang menjangkiti hampir seluruh penghuni dunia ini. Ini berlaku baik di negara-negara maju maupun negara berkembang seperti Indonesia.

Berkembangnya teknologi informasi pada dasawarsa terakhir menyebabkan ilmu pengetahuan berkembang dengan pesat. Selaras dengan perkembangan pengetahuan tersebut, kebutuhan pemakai atau pengguna akan jasa perpustakaan menjadi semakin meningkat dan semakin kompleks. Oleh karena itu, para pustakawan diharapkan untuk dapat lebih tanggap dan lebih jeli dalam mengidentifikasi kebutuhan pemakai informasi. Di masa mendatang, pustakawan diharapkan dapat lebih proaktif dalam penyediaan informasi sesuai dengan kebutuhan pemakai dan menyediakan layanan akses informasi secara cepat, tepat dan mudah kepada seluruh pengguna perpustakaan. Penyediaan sumber informasi tersebut dapat berupa karya cetak seperti buku serta monograf dan karya rekam seperti kaset, vcd, dvd, piringan hitam ataupun slide. Dalam hal ini, buku merupakan fasilitas utama dalam perpustakaan, seperti yang diungkapkan Retno (2010). Dengan demikian, koleksi bahan pustaka tersebut harus tetap terjaga dan terawat dengan baik untuk kemudian bisa dimanfaatkan oleh pengguna lainnya.

Menurut bahasa Sansekerta, istilah "perpustakaan" berasal dari kata pustaka yang artinya kitab, buku, sedangkan dalam bahasa Inggris perpustakaan berpadanan dengan kata library yang berasal dari kata 
Latin liber atau libri artinya buku. Asal kata inilah yang kemudian menjadi definisi awal tentang perpustakaan sebagai kumpulan buku, manuskrips dan bahan pustaka lainnya yang digunakan untuk keperluan studi atau bacaan, kenyamanan atau kesenangan (Webster's New World Dictionary, 1994).

\section{Perpustakaan}

UNDIKSHA merupakan jenis perpustakaan perguruan tinggi yang didirikan untuk menunjang aktivitas civitas akademik dimana perguruan tinggi berada. Menurut buku pedoman perpustakaan perguruan tinggi tahun 2004 diungkapkan bahwa perpustakaan perguruan tinggi merupakan unsur penunjang kegiatan Tri Dharma PT yaitu pendidikan, penelitian dan pengabdian pada masyarakat. Dengan demikian perpustakaan PT mempunyai fungsi edukasi, sumber informasi, penunjang riset, rekreasi, publikasi, deposit dan interpretasi informasi.

Terkait dengan definisi dan pentingnya peran perpustakaan dalam menunjang Tri Dharma Perguruan Tinggi maka dapat dipahami bahwa inti perpustakaan adalah karya cetak (buku, majalah, dII) dan karya rekam (kaset, VCD, DVD, piringan hitam, dIl) yang berfungsi sebagai sumber informasi, dan bahan rujukan riset. Dalam hal ini, tujuan pengguna perpustakaan datang mengunjungi perpustakaan adalah untuk mencari informasi yang diperlukan dengan jalan membaca atau mendengarkan/menonton rekaman informasi yang diinginkan. Mereka bisa membaca di tempat atau untuk koleksi tertentu bisa dipinjam untuk dibawa pulang.

Karena suatu koleksi perpustakaan bisa dipinjam untuk dibawa pulang, berarti bahwa perpustakaan perlu menerapkan suatu sistem untuk menjaga keamanan koleksinya dan juga untuk memastikan agar koleksi tersebut memiliki kebermanfaatan bagi orang banyak. Ini berarti bahwa pihak perpustakaan perlu memutuskan, misalnya, siapa saja yang boleh mengunjungi, khususnya meminjam koleksi buku-buku perpustakaan, berapa hari dan berapa banyak buku boleh dipinjam, dan bagaimana proses peminjamannya. Terutama sekali, pihak perpustakaan perlu untuk menerapkan suatu sistem yang membantu stafnya untuk memutuskan sanksi apa yang dikenakan pada pengguna jika mereka terlambat mengembalikan pada batas waktu yang sudah ditentukan atau bahkan menghilangkan (merusak) buku koleksi.

Peminjaman buku yang melewati ketentuan batas waktu akan menghambat kesempatan pengguna lain untuk meminjam. Oleh karena itu, perpustakaan khususnya perpustakaan milik Universitas Pendidikan Ganesha menerapkan sistem denda yang bertujuan untuk membuat peminjam tersebut jera dan tertib dalam meminjam buku koleksi. Denda tersebut adalah berupa uang sejumlah Rp. 100,- per hari. Kalau mereka terlambat 30 hari, mereka akan didenda Rp. 3000,-; atau kalau 60 hari, mereka akan didenda sejumlah Rp. $6000,-$ dst. Selain itu, kalau pengguna perpustakaan menghilangkan buku koleksi, mereka bisa dikenai satu dari sanksi berikut (a) mengganti dengan judul buku yang sama sejumlah dua eksemplar, (b) mengganti dengan subyek buku yang sama sejumlah dua eksemplar dengan melihat kesesuaian ketebalan buku, (c) mengkopy buku yang sama, atau (d) memberikan sejumlah uang yang sesuai dengan harga buku. Kalau mahasiswa menolak untuk mengikuti sanksi tersebut, mereka bisa dikenai sanksi administrasi yang berupa tidak boleh meminjam buku dalam waktu 
tertentu dan penahanan surat bebas pinjam untuk persyaratan wisuda.

Sanksi dikenakan terhadap suatu pelanggaran dengan tujuan untuk memberikan pengertian mengenai adanya aturan yang harus diikuti serta memberi peringatan terhadap tindakan yang salah. $\mathrm{Hal}$ ini sesuai dengan teori perilaku sosial oleh Skinner (dalam Mahmed, 2011) bahwa bila terjadi perilaku yang tidak diinginkan maka sebagai konsekuensi akan mendapat punishment/sanksi. Sebaliknya, jika terjadi perilaku sesuai tata aturan yang berlaku maka akan mendapat reward/penguatan/hadiah. Sanksi menjadi peringatan untuk mendidik dan tidak hanya berlaku bagi mahasiswa yang melanggar, melainkan juga anggota sivitas akedemika lainnya yang memiliki hak dan kewajiban yang sama terhadap peraturan yang berlaku.

Dengan demikian, sanksi dapat didefinisikan sebagai suatu tindakan yang diberikan kepada pemustaka, baik secara perorangan atau kelompok/organisasi, karena terbukti melakukan pelanggaran terhadap aturan yang berlaku. Sehingga, pelanggaran yang sama diharapkan tidak terjadi lagi.

Adapun jenis-jenis sanksi secara umum dapat dibedakan menjadi dua jenis, yaitu: (1) sanksi administrasi berupa teguran/lisan, peringatan/tertulis, pemberhentian sementara, dan pencabutan ijin; (2) berupa uang sesuai dengan aturan yang berlaku.

Sanksi berupa denda yang diberlakukan dalam perpustakaan UNDIKSHA adalah semata-mata untuk menjamin bahan pustaka dikembalikan, bukan untuk mengumpulkan uang. Namun kenyataannya, sanksi denda berupa uang tidak selayaknya efektif untuk diterapkan di perpustakaan UNDIKSHA merujuk pada hasil penelitian (Retno, 2010). Selanjutnya Retno (2010) menemukan bahwa pemberlakuan sanksi denda uang tidak lagi efektif untuk diterapkan dan pelanggaran tersebut terjadi karena beberapa faktor yaitu: lupa, tidak disiplin, kurang pengawasan dari pustakawan dan sanksi dianggap terlalu ringan, namun sanksi administrasi berupa pencabutan sementara hak pinjam masih dianggap memberatkan. Khusus untuk faktor lupa, Retno (2010) menyarankan untuk memperbaiki infrastruktur di bidang SDM agar selayaknya perpustakaan membentuk tenaga penagih buku "debt collector" untuk menagih buku dari pengguna yang terlambat mengembalikan buku.

Fenomena tersebut sangat menggelitik hati penulis untuk melakukan penelitian lebih lanjut untuk menyikapi hasil temuan penelitian Retno (2010), yaitu dengan sebuah solusi yang lebih interaktif, efektif dan efisien baik ditinjau dari segi waktu, ruang maupun tenaga. Adapun solusi yang ingin digagas adalah dengan perancangan program notifikasi berbasis komputer dengan program facebook. Penerapan teknologi sebagai sebuah solusi diimplementasikan merujuk pada perubahan perilaku sosial yang menyebabkan adanya transformasi budaya akan keberadaan teknologi informasi. Hal ini didukung oleh Bertrand dalam Faisal (1980), bahwa suatu diffusi/penyebaran budaya disebabkan oleh bentuk kebudayaan itu sendiri di mana benda/materi lebih cepat diterima oleh suatu masyarakat dibandingkan dengan ideologi/kepercayaan.

Tujuan yang ingin dicapai dalam penelitian ini adalah untuk mengetahui: (1) Pengembangan program notifikasi berbasis komputer dengan program facebook untuk 
memperlancar proses pengembalian buku pinjaman pada perpustakaan Undiksha, (2) Kualitas program notifikasi berbasis komputer dengan program facebook berdasarkan hasil validasi, (3) Efektiftas program notifikasi berbasis komputer dengan program facebook pasca implementasi.

\section{METODE PENELITIAN Desain Penelitian}

Penelitian ini bertujuan untuk mengembangkan, memvalidasi dan mengujicoba program notifikasi berbasis komputer dalam memperlancar proses pengembalian buku pinjaman oleh pemustaka perpustakaan UNDIKSHA, sehingga dalam menyusun kajian ini penulis menggunakan desain penelitian pengembangan (research and development). Dalam proses memperlancar pengembalian buku pinjaman ada dua indikator penting yaitu aspek pengingatan/pemberitahuan dan kontrol yang mendasari perlunya pengubahan sistem ke kondisi ideal yang diharapkan. Bertolak dari kedua aspek tersebut maka peneliti mendesain sebuah kajian pengembangan program yang mampu memberikan notifikasi/pemberitahuan via facebook dan kontrol secara otomatis tanpa batasan ruang, waktu maupun tenaga.

\section{Populasi dan Sampel Penelitian}

Populasi penelitian ini adalah seluruh pemustaka dari perpustakaan Undiksha, sedangkan sampelnya adalah seluruh pemustaka dari Jurusan Pendidikan Bahasa Inggris. Penentuan sampel tersebut dilakukan karena frekuensi keterlambatan pengembalian bahan pustaka tertinggi menurut database perpustakaan Undiksha adalah dari Jurusan Pendidikan Bahasa Inggris.

\section{Prosedur Penelitian}

Prosedur yang ditempuh oleh peneliti dalam mengembangkan program dengan mengikuti prosedur Borg dan Gall (1983): analisis kebutuhan, mengembangkan prototipe, validasi ahli dan revisi, ujicoba, dan revisi produk. Dalam menganalisis kebutuhan, peneliti melakukan studi pustaka serta menelaah permasalahan yang muncul pada sistem layanan perpustakaan UNDIKSHA. Kegiatan studi pustaka mencakup mengumpulkan literatur, membaca dan meringkas topik-topik relevan yang mendukung perancangan program.

Tahapan selanjutnya adalah mengembangkan prototipe (program awal) dengan menggunakan model prototyping. Dilanjutkan dengan validasi ahli dalam hal ini programmer sebagai ahli perancang program dan pustakawan sebagai ahli dalam bidang studi keperpustakaan. Revisi dilakukan jika ditemukan ketidaksesuaian program dengan tujuan/objektif dari rancangan program notifikasi. Kemudian, uji coba produk dilakukan dengan dua tujuan yaitu (1) untuk mengetahui apakah produk yang dibuat layak digunakan atau tidak; (2) untuk mengetahui sejauh mana produk yang dibuat dapat mencapai sasaran.

\section{Instrumen Penelitian}

Peneliti menggunakan tiga buah instrumen dalam pengumpulan data yaitu dengan kuesioner, catatan observasi/pengamatan dan wawancara. Instrumen yang digunakan dalam memperoleh data kuantitatif (tingkat kelancaran proses pengembalian buku pinjaman) adalah dengan kuesioner/angket dan catatan observasi/pengamatan 
terhadap database. Metode catatan pengamatan/observasi diterapkan dalam pengumpulan data, mempertimbangkan bahwa apa yang dikatakan seseorang sering kali berbeda dengan apa yang dilakukan, Bungin (2007). Dengan demikian, bias data dapat diminimalisir. Catatan observasi dilakukan dengan pemantauan database khususnya menyangkut tingkat keterlambatan pengembalian buku pinjaman setelah diterapkannya program notifikasi.

Angket merupakan alat pengumpulan data yang berisi kumpulan pernyataan tentang kajian yang akan diteliti yaitu program notifikasi pengembalian buku pinjaman berbasis komputer via facebook yang memuat empat butir indikator seperti relevansi, efisiensi, keakuratan dan kepuasan.
Tabel 1. Kisi-kisi Angket Program Notifikasi

\begin{tabular}{|c|l|c|}
\hline NO. & INDIKATOR & JUMLAH ITEM \\
\hline 1. & Relevansi & 5 \\
\hline 2. & Efisiensi & 3 \\
\hline 3. & Keakuratan & 3 \\
\hline 4. & Kepuasan & 5 \\
\hline
\end{tabular}

Selanjutnya, wawancara tak berstruktur juga diterapkan dalam pengumpulan data. Teknik wawancara tak berstruktur diterapkan bertujuan untuk menggali informasi lebih lengkap dan akurat dari sisi responden. Data hasil wawancara kemudian merupakan data kualitatif. Berikut adalah tabel matriks pengumpulan data yang di desain dalam penelitian ini.

Tabel 1. Matriks Pengumpulan Data

\begin{tabular}{|l|l|l|l|}
\hline \multicolumn{1}{|c|}{ Instrumen } & \multicolumn{1}{|c|}{ Sumber Data } & \multicolumn{1}{|c|}{ Jenis Data } & \multicolumn{1}{|c|}{ Waktu Penerapan } \\
\hline Kuesioner & Pemustaka & $\begin{array}{l}\text { Respon pemustaka } \\
\text { terhadap program notifikasi }\end{array}$ & $\begin{array}{l}\text { Pasca ujicoba } \\
\text { program }\end{array}$ \\
\hline $\begin{array}{l}\text { Catatan } \\
\text { observasi }\end{array}$ & Database & $\begin{array}{l}\text { Prosentase tingkat } \\
\text { keterlambatan pemustaka } \\
\text { dalam mengembalikan } \\
\text { buku }\end{array}$ & $\begin{array}{l}\text { Pengambilan data } \\
\text { sebelum dan } \\
\text { sesudah ujicoba }\end{array}$ \\
\hline $\begin{array}{l}\text { Wawancara } \\
\text { tak berstruktur }\end{array}$ & $\begin{array}{l}\text { - Ahli program } \\
\text { komputer } \\
\text { - Ahli bidang } \\
\text { keperpustakaan } \\
\text { - Pemustaka }\end{array}$ & $\begin{array}{l}\text { Respon programmer, } \\
\text { pustakawan yang } \\
\text { berkualifikasi, pemustaka }\end{array}$ & $\begin{array}{l}\text { Validasi ahli dan } \\
\text { revisi }\end{array}$ \\
& & \\
\hline
\end{tabular}

\section{Analisis Data}

Data yang terkumpul melalui instrumen selanjutnya dianalisis. Merujuk pada dua model data yang dihasilkan (data kuantitatif dan kualitatif) maka ada dua teknik analisis data yang diterapkan. Analisis data kuantitatif dilakukan dengan pentabulasian data hasil kuesioner dan catatan observasi pemantauan database.
Selanjutnya diterapkan teknik analisis deskriptif dari hitungan data kuantitatif. Tahapan dalam analisis data kualitatif yaitu melalui (1) mentranskripsi data, (2) pengelompokan data dan (3) menginterpretasikan data menggunakan teknik deskriptif kualitatif. 


\section{HASIL DAN PEMBAHASAN} Hasil Penelitian

Program notifikasi berbasis facebook merupakan program sederhana dan semi otomatis yang bertujuan untuk memberikan notifikasi pengembalian bahan pustaka. Program ini melibatkan langkahlangkah (1) pendeteksian pemustaka yang meminjam bahan pustaka 3 hari sebelum batas akhir peminjaman dalam dbase perpustakaan Undiksha bagi, (2) data itu kemudian diunggah ke website Undiksha, (3) dari website Undiksha kemudian dishare dengan facebook melalui fasilitas share, dan (4) nama akun pemustaka tersebut kesemuanya di add dan dikirimi notifikasi.

\section{Validasi}

\section{(i) Validasi Ahli}

\begin{tabular}{l}
\multicolumn{2}{c}{ Validasi ahli yang dilakukan } \\
merupakan validasi kualitatif yang \\
didapatkan melalui wawancara terhadap \\
programer dan pustakawan. Hasil
\end{tabular} wawancara dengan programer menunjukkan bahwa rogram tersebut, walaupun masih sederhana, bisa dikatakan cukup memadai dan bermanfaat untuk kebutuhan perpustakaan. Programer menunjukkan bahwa dalam kaitannya dengan keandalan (reliability), kebenaran (correctness), kemampuan menggunakan (useability), kemampuan memelihara (maintainability), kemampuan uji (testability), kemampuan interoperasi (interoperationalibility), keluwesan (flexibility), dan kepuasan menyeluruh (overall satisfaction) program sudah cukup baik.

Program notifikasi tersebut bisa menyelesaikan tugasnya dengan cukup akurat sesuai dengan tujuan pembuatannya yaitu untuk pemberian notifikasi pengembalian buku. Program tersebut juga gampang dipelajari dan dipakai. Selain itu, programer secara umum menyatakan cukup puas dengan program tersebut.

Ada suatu keberatan mengenai program tersebut karena masih belum bisa terkait dengan database secara langsung yang berarti programnya masih bersifat semi otomatis. Alasan yang mendasari kondisi ini adalah sulitnya untuk mengetahui dan mendeteksi program penulisan facebook yang masih sangat dirahasiakan dan tidak terbuka untuk umum. Walaupun demikian, program notifikasi tersebut sudah bisa dikatakan cukup memuaskan dan bisa menjalankan fungsi yang diharapkan dengan cukup baik.

Hasil wawancara terhadap
pustakawan mengungkapkan penerapan teknologi pemberian notifikasi berbasis komputer via facebook sangat bagus untuk diterapkan pada perpustakaan Undiksha. Hal ini merujuk pada paradigma perkembangan teknologi informasi yang mampu memberikan layanan online secara efektif, efisien, dan akurat tanpa batasan ruang maupun waktu. Pustakawan terwawancara juga berpendapat bahwa program ini perlu untuk dikembangkan seperti menyediakan layanan online perpanjangan masa pinjam, booking buku, layanan antar silang perpustakaan secara online sehingga pemustaka mendapat layanan yang memuaskan.

Mengenai aspek informasi yang tercantum dalam notifikasi, pustakawan terwawancara menyarankan agar menekankan pada aspek denda dengan bahasa yang lebih tegas dan singkat.

Hasil wawancara dengan pustakawan juga mengungkapkan bahwa penerapan program notifikasi mampu menekan keterlambatan pengembalian buku dan meningkatkan kedisiplinan pemustaka akan tertib perpustakaan. Hal ini tentu saja 
berdampak langsung terhadap kelancaran sirkulasi buku dan mengurangi pengendapan ataupun kehilangan koleksi pustaka oleh pemustaka yang tidak bertanggungjawab.

\section{(ii) Validasi Pemustaka}

Untuk mengetahui isi, keterbacaan dan efektivitas dari program notifikasi ini bagi pemakai, maka peneliti juga melakukan validasi pemustaka. Validasi ini dilakukan dengan menyebarkan angket pasca ujicoba terhadap 100 pemustaka. Hasil angket ini kemudian ditindaklanjuti dengan proses wawancara.

Angket tersebut mengandung empat indikator penting seperti relevansi, efisiensi, keakuratan dan kepuasan pemakai. Ratarata $93,4 \%$ responden setuju bahwa program notifikasi relevan untuk diterapkan dalam artian program tersebut sangat bermanfaat dalam mengingatkan pemustaka untuk mengembalikan buku pinjaman dan meminimalisir/mengurangi sanksi denda yang diberikan, mudah diakses dan membantu pemustaka dalam menumbuhkan kedisiplinan akan tertib perpustakaan. Ratarata $93,67 \%$ responden setuju bahwa program notifikasi efisien dalam penerapannya terkait dengan waktu pemberian notifikasi, dan kemudahan pengoperasian. Rata-rata 95,67\% responden setuju dengan pernyataan bahwa program notifikasi memiliki keakuratan dalam penerapannya terkait dengan selalunya tepat waktu pemberian notifikasi, kejelasan informasi dan susunan bahasa notifikasi. Rata-rata 93,6\% responden puas dengan penerapan program notifikasi tersebut terkait dengan tampilan, kemudahan akses dan mereka juga berharap agar program ini terus berlanjut.
Hasil wawancara mendukung temuan yang diperoleh melalui angket. Pemustaka terwawancara menyatakan mendukung program notifikasi berbasis komputer melalui facebook diterapkan di perpustakaan Undiksha merujuk pada perkembangan teknologi informasi di era globalisasi yang serba cepat, tepat dan efisien. Responden merasa diuntungkan dengan adanya layanan interaktif dari perpustakaan dalam hal mengingatkan responden untuk mengembalikan buku tepat waktu. Hal ini disebabkan karena faktor lupa, tidak disiplin, kesibukan perkuliahan ataupun karena alasan libur yang membuat responden terlambat mengembalikan buku. Tentu saja keterlambatan itu sendiri berimplikasi pada sanksi denda yang harus responden bayar untuk Rp.100,- per hari per buku.

Responden juga mendukung penggunaan aplikasi facebook dalam pemberian notifikasi merujuk pada keaktifan responden menggunakan jejaring sosial tersebut. Responden menyatakan hampir seluruh mahasiswa mempunyai alamat facebook dan online rata-rata setiap hari. Menurut responden facebook sendiri sudah merupakan tren kehidupan masa kini yang menunjukkan prestise tersendiri dalam masyarakat. Disamping itu situs facebook juga dianggap mudah untuk diakses dan dioperasikan. Dengan demikian pemberian notifikasi melalui facebook sudah pasti diterima dan dibaca oleh pemustaka.

Namun, ada sedikit keluhan dari responden yaitu tampilan notifikasi agar lebih variatif dan atraktif/menarik sehingga pemustaka merasa senang untuk menerima pemberitahuan dari perpustakaan. Untuk rencana kedepan, responden menyarankan untuk menambah layanan online perpustakaan Undiksha seperti 
perpanjangan masa pinjam online, booking online dan catalogue online. Selain menggunakan aplikasi facebook, responden juga menyarankan alternatif lain pemberian notifikasi melalui sms via telepon genggam dan pengumuman tertulis.

\section{Hasil Ujicoba}

Observasi database dilakukan untuk mengetahui tingkat keterlambatan pemustaka sebelum dan sesudah diterapkannya ujicoba program notifikasi.
Hal ini dimaksudkan untuk membandingkan tingkat keterlambatan dan pada gilirannya akan memperlihatkan efektivitas dari program tersebut dalam menekan keterlambatan pengembalian bahan pustaka.

Ujicoba program notifikasi pengembalian buku pinjaman dilaksanakan pada peminjaman bulan September. Sedangkan bulan Juli dan Agustus dijadikan sebagai pembanding sebelum diberlakukannya program.

Tabel 2: Prosentase Tingkat Keterlambatan Pemustaka

\begin{tabular}{|c|c|c|c|c|c|c|}
\hline BULAN & $\begin{array}{c}\text { PERLAKUAN } \\
\text { PROGRAM } \\
\text { NOTIFIKASI }\end{array}$ & $\begin{array}{c}\text { PEMINJAM } \\
\text { PER } \\
\text { ORANG }\end{array}$ & $\begin{array}{c}\text { KEMBALI } \\
\text { TEPAT } \\
\text { WAKTU } \\
\text { PER } \\
\text { ORANG }\end{array}$ & $\begin{array}{c}\text { TERLAMBAT } \\
\text { PER ORANG }\end{array}$ & $\begin{array}{c}\text { VARIASI WAKTU } \\
\text { KETERLAMBATAN } \\
\text { PER HARI }\end{array}$ & $\begin{array}{c}\text { PROSENTAS } \\
\text { E KETER- } \\
\text { LAMBATAN } \\
(\%)\end{array}$ \\
\hline Juli & Tidak & 53 & 8 & 45 & $1-411$ & 84,9 \\
\hline Agustus & Tidak & 99 & 56 & 43 & $2-20$ & 43,4 \\
\hline September & Ya & 188 & 166 & 21 & $2-5$ & 11,2 \\
\hline
\end{tabular}

Tabel 2 menunjukkan bahwa terdapat perbedaan prosentase keterlambatan sebelum dan sesudah penerapan program notifikasi dengan variasi waktu keterlambatan yang cukup mencolok. Pada bulan Juli prosentase keterlambatan adalah sebesar 84,9\%; bulan Agustus sebesar $43,4 \%$ dan bulan September pasca ujicoba sebesar $11,2 \%$.

\section{Pembahasan}

Secara umum, program notifikasi pengembalian buku melalui situs jejaring sosial facebook sudah dapat dioperasikan namun masih bersifat sederhana dan semi otomatis. Hal ini merujuk pada belum tersedianya aplikasi pengiriman file data antara suatu sistem database ke sistem facebook secara otomatis seperti yang dapat dilakukan pada pengiriman melalui email. Namun demikian dalam situs facebook sudah tersedia fasilitas share yang kemudian dimanfaatkan oleh programmer dalam merancang program notifikasi. Program pendeteksian pemustaka yang harus segera mengembalikan buku pinjaman tiga hari sebelum batas akhir pengembalian dirancang terlebih dahulu oleh programmer. Data pemustaka tersebut kemudian diupload di website Undiksha. Proses pengirimannya melalui beberapa langkah yaitu dari database perpustakanwebsite Undiksha/Perpustakaan-share facebook. Program notifikasi pengembalian buku pinjaman melalui facebook amatlah mudah dioperasikan baik dari pihak programmer maupun dari pihak pemustaka. Pemustaka dapat dengan mudah membuka file pesan tempat dikirimkannya notifikasi dan membaca 
pemberitahuan sekaligus mengirimkan balasan atas pemberitahuan tersebut. Tidak jarang pemustaka membalas pengiriman notifikasi tersebut dengan memberikan ucapan terimakasih, dukungan, saran, maupun menanyakan seputar koleksi perpustakaan. Terkait dengan hal ini, program notifikasi dapat difungsikan sebagai ajang kontak langsung "link" pemustaka dengan pustakawan selain berfungsi untuk pengiriman notifikasi.

Hasil validasi yang dilakukan dengan cara wawancara programer, pustakawan dan penyebaran angket dan wawancara pemustaka menunjukkan hasil yang positif terhadap keberadaan program notifikasi berbasis facebook tersebut. Hal ini terkait dengan relevansi, efisiensi, keakuratan dan kepuasan pemakai yang kemudian berujung pada harapan agar program ini tetap dapat dilanjutkan dan disempurnakan.

Merujuk pada tabel 2 tentang prosentase keterlambatan pemustaka dalam mengembalikan bahan pustaka terbetik bahwa pada bulan Juli dan Agustus yang mana program notifikasi belum diimplementasikan, prosentase keterlambatannya adalah $84,9 \%$ dan $43,4 \%$. Sedangkan, pada bulan September ketika program notifikasi diperkenalkan terjadi penurunan yang cukup drastis yaitu $11,2 \%$. Untuk gambaran visualnya, lihat bagan 1 .

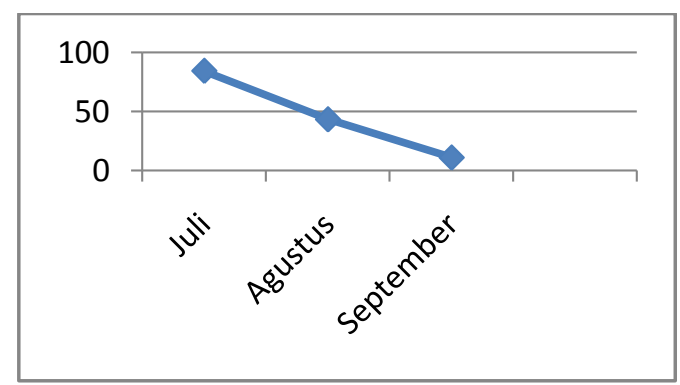

Bagan 1: Grafik prosentase keterlambatan
Bagan 1 menunjukkan adanya penurunan yang mencolok dari bulan Juli dan Agustus ke bulan September. Hal ini berarti bahwa program notifikasi tersebut mampu untuk meminimalisir prosentase keterlambatan pengembalian bahan pustaka.

Hasil analisis dan refleksi yang dilakukan terhadap ke $11,2 \%$ pemustaka yang terlambat mengembalikan bahan pustaka ditemukan bahwa sebagian besar dari mereka adalah pemustaka yang tidak bisa dicapai melalui facebook. Mereka tidak bisa dicapai karena mereka tidak mengadd perpustakaan Undiksha dalam akun facebook mereka dan mereka juga menggunakan nama yang cukup bervariasi dan berbeda dengan nama resmi, sehingga sulit untuk dideteksi melalui fasilitas search. Hal ini semakin menguatkan bahwa program notifikasi dapat meminimalisir keterlambatan pengembalian bahan pustaka.

\section{PENUTUP}

Melalui kajian ini tersedia suatu program notifikasi berbasis komputer via facebook yang sederhana, tapi memiliki kebermanfaatan yang tinggi dalam membantu pustakawan untuk mengelola bahan pustaka secara lebih efektif dan pemustaka untuk mengingatkan pengembalian buku dengan segera. Program ini memiliki beberapa keunggulan, selain tentu juga kelemahan, seperti mudah dioperasikan, mudah diakses, cepat, akurat dan lain-lain. Sehingga, disarankan bagi pihak perpustakaan atau yang tertarik untuk menerapkan dan jika mungkin memberikan umpan balik bagi kesempurnaan program yang telah disusun tersebut. 


\section{DAFTAR RUJUKAN}

Basuki, S. 1993. Pengantar IImu Perpustakaan. Jakarta: PT Gramedia.

Basuki, S. 1994. Periodisasi IImu Perpustakaan Indonesia. Bandung: Rosda Karya.

Soedibyo, N. 1987. Pengelolaan Perpustakaan (Jilid 1). Bandung: Penerbit Alumni.

Soedibyo, N. 1987. Pengelolaan Perpustakaan (Jilid 2). Bandung: Penerbit Alumni.

Bungin, B. 2007. Metodologi Penelitian Kualitatif. Jakarta: PT Raja Grafindo Persada.

Hartana, I.K. 2004. Efektivitas Penerapan Sanksi Denda terhadap Pemakai yang Terlambat Mengembalikan Buku pada Perpustakaan IKIP Negeri Singaraja. Laporan Penelitian ISS yang tidak diterbitkan. UPT Perpustakaan IKIP Negeri Singaraja.

Welnadi. 2010. Dinamika Informasi dan Hukum di Dunia Maya. Jurnal Dialog Kebijakan Publik. 10(8).

Hamad, I. 2010. Transformasi Kultural Menuju Masyarakat Informasi. Jurnal Dialog Kebijakan Publik. 10(35).

Anonimus. 2010. Perpustakaan tanpa Denda, Mungkinkah? Jurnal IImiah Perpustakaan Negeri Malang. 3(3).

Widiasa, I.K. 2007. Manajemen Perpustakaan Sekolah. Jurnal IImiah Perpustakaan Negeri Malang. 1(13).

Mahmed, P. 2011. Perilaku Sosial. www.google.com. 2/14/2011 12:35 AM

Wikipedia. 2011. Jejaring Sosial. www. Wikipedia.com. 2/7/2011 10:31 AM

UPT Perpustakaan Undiksha, 2008. Buku Panduan Penggunaan Perpustakaan Undiksha. Singaraja: Universitas Pendidikan Ganesha.

Retno, N.G.K.R. 2010. Efektivitas pemberian Sanksi di Perpustakaan Universitas Pendidikan Ganesha. Laporan Penelitian DIPA yang tidak dipublikasikan. Lembaga Penelitian UNDIKSHA.

Ladjamudin, A.B. 2005. Analisis dan Desain Sistem Informasi. Yogyakarta: Penerbit Graha IImu.

Corbin, J. 1985. Managing the Library Automation Project. Canada: Oryx Press.

Faisal, S. 1980. Sosiologi: Kerangka Acuan, Metode Penelitian, Teori-Teori tentang Sosialisasi, Kepribadian dan Kebudayaan. Surabaya: PT Bina IImu.

Rowley, JE.1980. Computers for Libraries. London: Clive Bingley.

Depdiknas RI. 2004. Buku Pedoman Perpustakaan Perguruan Tinggi Edisi Ketiga. Jakarta: Depdiknas RI Dirjendikti.

Borg, W.R. \& Gall, M.D. 1983. Educational Research: an Introduction. London: Longman, Inc.

Kamus Besar Bahasa Indonesia edisi ke 3. 2005. Jakarta: Balai Pustaka.

Webster's New World Dictionary. 1994. New York: Prentice Hall. 